\title{
New trends in innovation and customer relationship management: a challenge for market researchers
}

\author{
Dr Stan Maklan \\ Professor Simon Knox \\ Professor Lynette Ryals
}

\section{Abstract}

For decades, one of the key roles of market research has been to help companies forecast customer acceptance of innovation and of changes to the market mix (the 4 Ps). However, traditional market research is in danger of being left behind by new practices in Sales, Marketing and R \& D. Reflecting an increasingly participative approach to customer relationships, these disciplines are moving towards customer involvement and co-creation of value rather than innovation mainly generated by head office and only then tested among customers (Roberts, Baker and Walker, 2005). Co-creation involves working participatively with customers to enhance the value customers get when buying and using goods and services. It enables firms to understand and respond to deeper and more valuable customer needs and reduces the inherent risks of innovation. Nor is this increasing trend towards co-creation limited to new product introduction. As companies invest in customer relationship management (CRM) programmes, they need to design new forms of relationships with those directly affected: their customers. As customers use internet-related technologies to manage their relationships with suppliers, co-creation will become a more important component of innovation and growth strategies. In this context, traditional market research approaches begin to look outdated. The authors illustrate how Action Research can provide tools and methods by which market researchers can assist and improve the co-creation process with a case study of a dot.com company. The implications for market researchers and research practices are identified.

Dr Stan Maklan is Senior Lecturer in Strategic Marketing at Cranfield School of Management.s.maklan@cranfield.ac.uk

\section{Professor Simon Knox holds the Chair in Brand Marketing at Cranfield School of} Management.s.knox@cranfield.ac.uk

Professor Lynette Ryals holds the Chair in Strategic Sales and Account Management at Cranfield School of Management.Lynette.ryals@cranfield.ac.uk

Please address all correspondence to Dr Maklan either by email or at Cranfield:

Faculty of Strategic Marketing, Cranfield School of Management, Cranfield,

Bedfordshire, MK43 AOL, UK 


\section{New trends in innovation and customer relationship management: a challenge for market researchers}

\section{The Participatory Trend}

It is becoming harder to decipher the modern customer through our traditional market research methods alone. The "new consumer" often defies neat categorisations offered by market segmentation and exhibits apparently contradictory or inconsistent patterns of attitude and behaviours that may make interpreting survey-generated data challenging. Groups and depth interviews can provide additional customer insight but are still not strongly predictive of behaviour. With respect to companies' experiencebased marketing offers, it is the consumers that create much of the meaning (Rose and Wood, 2005); they are no longer passive recipients of brand offers. Consumers can now more readily evaluate a company's marketing approach and accept or reject claims based on their own knowledge (Ind and Riondino, 2001). Additionally, they can also consult and collaborate with other consumers in virtual communities of interest (Kozinets, 1999). By doing so, they are placing a value on peer-group reviews and consumer-to-consumer dialogue to evaluate one-way marketing messages and controlled advertising sent out by firms. In business marketing, cross-functional business processes that drive contemporary buyer behaviour, challenge our traditional concepts of the decision-making unit and the categorisation of players into users, decision-makers and authorisers of purchasing decisions (Baker and Mouncey, 2003).

Leading-edge companies are changing their interaction with both customers and employees because they now have a far greater influence in new product and service development and market strategy implementation. The participatory approach pays off: co-developing solutions increases customer value and yields far greater returns than do traditional methods based upon researching customer needs and responding sequentially with new products (Lilien, Morrison, Searls, Sonnack and von Hippel, 2002). Companies are also interacting more directly with customers through blogs, using them to assess ideas and offers, assessments that used to be the domain of the traditional market research function (DeFelice, 2006).

In response, market research is being applied in closer proximity to customers and through interacting more directly with them, sacrificing some of its traditional arm's length neutrality for richer and more insightful data. A recent paper in IJMR suggested that experimental methods of research may yield better insight than traditional marketing research (Ryals and Wilson, 2005). Similarly, Ethnography has become increasingly popular for researching consumers and users of technology products over the past few years. Other firms have created special consumer panels to help them assess innovation and communications. Market researchers must therefore adapt to a more interactive world and research more collaboratively, or at least interactively, with respondents (Palmer, 2005). These respondents will want to understand this process of collaboration and indeed may guide it for their own aims as opposed to the aims of the researcher. We predict that, more and more, market researchers will use participatory research methods to support their firms' co-creation efforts in the future. 


\section{Co-Creation of Value}

Marketing's origin can be traced to an offshoot of economics and was first defined as facilitating exchange (Kotler, 1972). The economist's view of exchange is straightforward; in perfectly competitive conditions, the price paid for goods or services reflects perfectly all information about their cost and value (Marshall, 1991). However, this view has recently been challenged by the co-creation perspective. Here, value is not created through the act of exchange: instead, it is created by customers as they use the goods and services (Vargo and Lusch, 2004). Therefore, the customer is central to the value creation process and not merely a passive receiver of companies' well-crafted offers. This value-in-use argument pushes marketing to consider customers' needs, buying and consumption processes more than their firms' brands and offers (Womack and Jones, 2005). In their paper, Womack and Jones use the example of personal home computing which now often involves the challenge of connecting with the user's digital camera, their PDA and their phones. They argue that customers are less interested in the specific features of all of these items than providers seem to think and what they really want is for everything (hardware, software and support services) to work together reliably and seamlessly with minimum drain on their time and emotions. The data requirements for understanding customers' value-in-use are richer, more context specific and less amenable to being revealed through arms-length research techniques than the data requirements for assessing customers' reactions to standardised brands/offers.

Together, the combination of customer value-in-use and their status as co-creators of value present a formidable challenge to the market researcher's ability to observe and understand customers from a detached perspective. Increasingly, organisations are trying to work collaboratively with customers for mutual gain. Traditional market research cannot explore this new territory. Instead, researchers need to adopt collaborative research methodologies. Often customers do not fully understand the potential value-in-use that they can derive from suppliers' products and services; the process of value identification must therefore be an iterative process between the company and its customers. Among all the participative research methods, the need for iterative learning and development makes Action Research particularly well suited to the task.

\section{Action Research (AR)}

Social scientists concerned with disadvantaged populations (Lewin, 1973; Reason and Bradbury, 2000), have long used collaborative research to promote the development of knowledge useful to these populations. Their view is that, as the disadvantaged use research to create knowledge to understand and improve upon their situation, they create a self-sustaining and liberating community of learning and progress. The main collaborative research approaches are illustrated in Appendix 1 and, whilst there is no rule book for collaborative research, they do share some common elements, namely: 
1. The research is conducted with the commitment of the 'researched' and is conducted in their interest, as opposed to the interest of the researcher (or the researcher's organisation).

2. The 'researched' wish to improve their day to day performance in a matter of immediate importance to them. Research is not conducted to produce "shelfware" or justification for decisions already taken.

3. The focal researcher is, in fact, a co-researcher, a peer-member of the research team. The focal researcher provides expertise to the process, but is conscious of his or her role and seeks to ensure that their co-researchers lead the research. In a business context of AR, co-researchers are normally managers who face important decisions affecting their day to day operational performance.

4. The research process is iterative. Knowledge is created through cycles of reflection upon practice, experimentation, further reflection, sharing reflections, further experimentation and so forth. Research is a learning process rather than a discrete project and co-researchers determine the length of the process and its outputs.

5. The validity and the success of the research are judged by the extent to which co-researchers act upon the learning they generate - action based upon informed and committed action (Clark, 1972). It is not essential that the knowledge generated is generalisable or repeatable, only that the coresearchers improve their day to day practice through committed action and that the process of creating knowledge is transparent and observable. The extent to which managers commit to action, based upon the information and the outcomes of collaboration generated through the AR project, is therefore a critical test of the validity of the method. Arguably, it is precisely because managers design both the research objectives and its methods which generate the capabilities to improve their day to day performance, that informed commitment to action arises (Argyris, 1973).

The authors contrast AR inquiry with expert-led market research, often created with the top team's agenda in mind. The knowledge generated from the latter process rarely creates the informed commitment to action from which organisations achieve significant outcomes. In AR, the participants are the researchers. Thus, AR is research carried out with, rather than on, the research subjects. Participation and ownership of the results of AR are crucially important when generating knowledge that will ultimately drive customer relationship policies and practices; effective and committed front-line employees are critical to this success. It is therefore no coincidence that the project presented in this paper entails a strong element of relationship marketing.

Although there are numerous variations of collaborative research, this paper focuses on the most relevant for market research purposes - Action Research (AR). The philosophical underpinning of $A R$ is Social Construction which takes the view that reality is created through people's ever-expanding cycles of action-reflectiontheorising (Berger and Luckmann, 1966). Researchers observe that evolving reality 
by engaging with these cycles, the focal point of which is people's informed and committed action based on the co-created knowledge (Berger and Luckmann, 1966; Argyris, 1973; Argyris and Schön, 1978; Argyris, Putnam, and McLain Smith, 1985; Skolimowski, 1994; Reason, 2001).

AR can be used across a broad spectrum of organisations; researchers have reported using AR amongst health care professionals, IT managers, police officers, educators and disadvantaged communities in the developing world (Checkland, 2000; Reason and Bradbury, 2001; Breu and Peppard, 2003). The authors have personal experience with five commercial organisations: a renowned manufacturer of executive cars, a dot.com betting company, two major financial services firms and a leading UK charity. In each of these five organisations operational managers involved face complex strategic decisions for which there is little consensus internally, no readily identifiable road-map to follow and severe limitations upon the ability of traditional market research methodologies to inform those decisions. Faced with unquestioningly accepting the counsel of outside consultants, the five firms decided to create the knowledge and insight relevant to their particular contexts and ambitions.

Given the context-specific nature of AR projects, the authors cannot offer a rigid "step by step" methodology for AR that is generalisable and repeatable as would be the case for many traditional research methodologies; nor can we explore more than one of these projects if we are to do justice to the AR methodology, process and discussion of outcomes here. Consequently, in this paper we explore our AR research in a dot.com betting company to illustrate the nature of $A R$ in practice and conclude with some generalisable implications for researchers. 


\section{Case Study of an Action Research Inquiry}

The following case study illustrates the successful use of AR in the context of marketing; summarising the results of an inquiry with pioneer in the online betting market, hereafter referred to as Wage.com.

\section{Company Background}

Wage.com offered a web-based means for consumers to negotiate bets and odds directly with other consumers, disintermediating traditional betting shops, and reducing commission costs substantially for its customers. At its conception, Wage.com anticipated that the online, peer-to-peer interaction amongst site users (people who wish to wager online) would create a unique community that was valued by customers and thus "lock in" groups of online betters. It launched its service in the UK with a traditional mass marketing mix of advertising and promotion, and attracted the largest number of online betters in the market. At the same time, another UK-based competitor entered the market offering an anonymous betting exchange whereby individuals' bets (back or lay') were aggregated and resolved through the exchange without individuals having to parcel bets for individual takers or communicating directly with takers of their bets. Exchange betting attracted fewer, but heavier betters. Despite having more consumers, Wage.com had only $4 \%$ of the online betting market (Wood, 2002) by the end of the launch year against its competitor's $50 \%$. Market share is vital in this business because serious betters will always opt for large (liquid) betting sites that can accommodate their substantial bets.

Wage.com therefore needed to build liquidity quickly to survive and was poised to reinforce its mass marketing strategy in order to do so. Its first decision was to abandon peer-to-peer betting in favour of an exchange and redirect its communications to target serious, larger betters. However, senior managers worried that a "me-too" offer could help Wage.com close the gap but unlikely enable it to catch up with and eventually overtake its larger rival. Wage.com thought it needed to convince sufficient numbers of large betters to switch to its site but were unsure how to convince them.

The marketing officer at Wage.com, a highly experienced consumer marketer with deep experience commissioning and analysing research, was not convinced that traditional market research methods could inform these decisions adequately or that an actionable research brief could be defined. Online betting was so new that there were issues with the quality of data that one could obtain from respondents; nor were there reliable external sources of data or insight that could be leveraged. The online environment was changing so rapidly and profoundly that Wage.com questioned the usefulness of surveygenerated insight; by the time the questionnaire was designed, implemented and analysed, the validity of the data and conclusions would be doubtful. Managers were all too aware of many apocryphal stories of well-researched but spectacular dot.com failures. 
The authors explored establishing an Action Research inquiry with the marketing team of Wage.com. Seeking knowledge in the context of improving team or business performance is characteristic of Action Research. AR is a method concerned with improving the ways in which managers/participants do things (their practice) as well as with generating knowledge. We agreed upon a process for raising managers' tacit knowledge (Polanyi, 1976) of Wage.com's marketing effectiveness through cycles of reflecting upon their marketing actions (Ambrosini and Bowman, 2001), a form of double loop learning (Argyris and Schön, 1978) that leads to the development of the new and better marketing capabilities (Zollo and Winter, 2002); capabilities that Wage.com sought in order to overtake its rival. To promote this virtuous cycle of reflection upon action, learning and capability development, the authors introduced various frameworks and tools to the process; tools that the Wage.com managers evaluated and adapted to suit the specific context. These tools are described in detail in Appendix 2. 


\section{The Action Research Process at Wage.com}

The key differences from starting up a traditional market research project are the more flexible and evolving research agenda, the co-creation of the research instrument (rather than a researcher-designed questionnaire), and an expectation of multiple participation over a period of time rather than one-off interviews or focus groups.

As with most AR projects, this inquiry was structured around a series of work-cycles interspersed with experiments, trials or other activities; these activities promote the managers-cum-researchers' reflection and preparation for the next session. The process continues as long as the inquiry wishes; normally between three and nine months. In this case, there were three work-cycles (Figure 1) and, due to the hyper dynamic nature of the dot.com world, the cycles were completed in less than eight weeks.

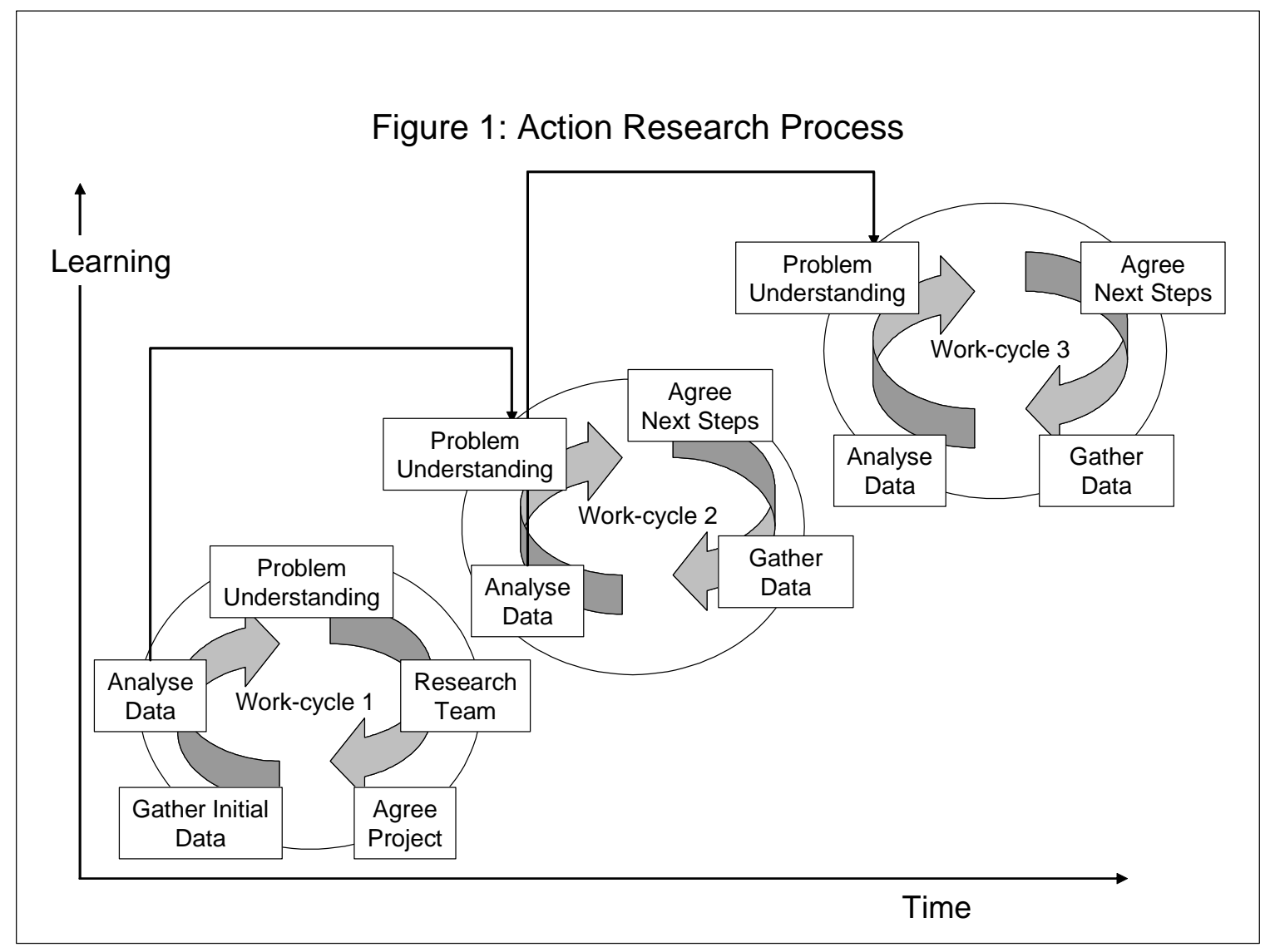

\section{Work-Cycle 1}

An initial meeting between the authors and interested managers initiated the first work-cycle. The meeting discussed the nature of the marketing issues faced, the team's interest in resolving them, how the inquiry was to be organised, what was 
most important to personal and organisational agendas and, finally, what the team wished to do with the output of the research. It is vital at this set-up stage that a team of co-researchers forms on the basis of democratic decision-making and a willingness to critique both the work and the reasons for undertaking the work. This form of critique is fundamental to most participatory approaches to knowledge generation (Coghlan and Brannick, 2001) and helps ensure that the inquiry is being conducted in the interests of the co-researchers. The first meeting identified the initial interest of the managers as developing the relationship marketing capabilities that would allow Wage.com to recruit important betters to its site and retain them on a sustainable basis. The authors introduced a marketing capabilities framework (Appendix 2 - Figure 5) and it was decided to organise an inquiry with that as a starting point.

Tools designed for the capabilities framework provided focus and purpose to the rest of the first work-cycle which comprised a formal workshop followed by assignments and preparation for the next work-cycle. The workshop used capabilities scoring tools (Appendix 2 - Figure 6) to promote action (filling in the tool) and reflection (individual and collective). Through cycles of critique and reassessing Wage.com's current marketing capabilities, managers better understood Wage.com's current capabilities and the marketing assets that support those capabilities such as brand, customer insight and customer base. Further work on assessing current capabilities and marketing assets was agreed. This work was done in pairs and used empirical data to support the reflections wherever possible.

Assignments typically comprise a mix of gathering internal data, interviewing customers, trying new customer service solutions, testing new offers, researching competitors, completing a framework being used in the project or merely reflecting further upon the issues. A characteristic of the AR inquiry is the use of multiple research methods, managerial frameworks and a diverse set of tools and techniques. In this case, some assignments focused on the behaviour of customers through data and direct conversations. Managers identified the presence of key market-makers who attracted a following of serious customers. By recruiting such market-makers, the inquiry team understood that it could build market share quickly because the market-makers were a big enough attraction to pull users from its larger rival. Other assignments investigated the nature of Wage.com's key marketing assets identified during the workshop to determine if they were potential sources of sustained competitive advantage versus its larger rival. To do this, members of the inquiry team engaged with the VRIN analysis described in Appendix 2. 


\section{Work-cycle 2:}

Work-cycle 2 was initiated by a workshop during which the team discussed and built upon what they had learnt and determined the issues that they wanted to explore.

During a second workshop, Wage.com's managers came to an important realisation. At the start of the inquiry, they felt that Wage.com was a superior mass marketing organisation versus its larger rival. However, the AR process made the research team aware that Wage.com was compensating for its relative lack of liquidity through effective management of the overall network of its betters. For example, if managers saw a market-maker laying heavily on greyhounds, they knew that the propensity to lay on greyhounds was far greater than to back and that Wage.com would need to recruit to the site a much higher number of greyhound layers in order to compensate. Wage.com had built an empirically based understanding that permitted it to identify partner web sites rich in greyhound backers. It would increase referral incentive payments to these partner sites, thereby cost effectively re-establishing the Wage.com site's equilibrium and allowing all bets to clear. The team articulated that Wage.com's true marketing capability was derived from managing a highly interrelated series of relationships between winners and losers, backers and layers across a number of betting interests.

The team agreed to follow the workshop with data gathering assignments to validate this and to test Wage.com's network marketing capabilities against its biggest rival to determine if this was the means by which Wage.com could build a strategy to overtake it. The assignments concluded that network marketing was a source of competitive advantage and that Wage.com's attendant level of customer and network insight was the marketing asset that would enable it to build a winning marketing strategy.

\section{Work-cycle 3}

By the time of the third and final workshop, the team had already implemented many of the actions that were to be discussed. The workshop began by developing a profile for Wage.com's future marketing capabilities based upon developing and leveraging its superior network marketing. Some investments were postponed pending further inquiry, such as brand development, in favour of investing in that which would leverage its insight with the key market-makers. A new customer service policy had been developed during the previous work-cycle that helped customer service people differentiate treatment between typical customers, heavy betters and market-makers. The subtle but critical difference between a profitable customer that bets frequently, and one that can bring a following from a rival was recognised and acted upon. A customer bulletin board that had been discontinued was reinstated. New offers for bookmakers and market-makers were already being prepared for launch. The head of product and site development had been briefed on the AR inquiry and asked to join in on the follow up, thus creating an enhanced link between the marketing function and development. 
This blurring of learning and doing is typical of all good AR enquiries. Learning occurs through cycles of doing-reflecting-creating new hypotheses-testing. We contrast this with a typical market research-informed decision that occurs sequentially: problem identification, research brief, research, analysis, recommendations, action planning, implementation and assessment.

\section{Implications for Researchers}

Action Research puts additional demands upon market researchers who volunteer to participate in a research project. These demands arise from the research process which tends to be longitudinal, highly interactive, evolving and requiring careful facilitation whilst continually challenging the research objectives. Traditionally, market researchers and managers are detached from the inquiry process so as not to contaminate the data. Third party conducted interviews or focus groups, unbiased questionnaires and random sampling are the conventional instruments that create valid research into marketing issues. The market researcher's core skills need to include understanding the research problem, choosing the appropriate instruments, ensuring unbiased-scientific data gathering and insightful analysis of the results. AR does not obviate the need for these core skills; however, it does remove the detachment from the process. The participatory perspective does not accept that any research is truly "unbiased" and asks not that the researcher is artificially detached from it, only that researchers are aware of, and manage their role upon, the groups' dynamics (Figure 2). 
Figure 2: Action Research Versus Traditional Market Research Methods

\begin{tabular}{|c|c|}
\hline Traditional Market Research & Action Research \\
\hline Attempting to be value-free & $\begin{array}{l}\text { Developing social systems; value- } \\
\text { laden }\end{array}$ \\
\hline Focused on the present & Aiming for more desirable future \\
\hline Representative samples & A case is a sufficient sample \\
\hline Subjects = objects to study & $\begin{array}{l}\text { Subjects = Self-reflective systems with } \\
\text { which to collaborate }\end{array}$ \\
\hline $\begin{array}{l}\text { Researcher active at beginning and } \\
\text { end of project }\end{array}$ & $\begin{array}{l}\text { Researcher active and re-evaluating } \\
\text { throughout project }\end{array}$ \\
\hline Highly specialised & Interdisciplinary \\
\hline No role tension & $\begin{array}{l}\text { Role tension for researcher between } \\
\text { change agent and researcher }\end{array}$ \\
\hline Goal is to generate or test theory & Goal is to generate change \\
\hline
\end{tabular}

Source: Based on Aguinis, 1993

The main implication for market researchers at a personal level is the need for greater self-awareness in the research process. Critical self-reflection is necessary at each stage of the research protocol: the tasks being performed, the objectives of the tasks, the quality of the researcher's contribution, the quality of co-researchers' contributions and the researcher's role within the group. There are a number of tools and techniques for developing such self-awareness; however, in the authors' experience, a toolset can be as simple as a divided page of paper and high quality audio recording device. Immediately after any workshop, the authors will listen to the audio recording and, on the left hand side of a page (or computer screen), summarise the content of the discussion whilst on the right hand side, note how they felt during particular points in the discussion and record any reflections on the conversations that arise from listening to the recording, as Figure 3 illustrates: 


\begin{tabular}{|c|c|}
\hline \multicolumn{2}{|c|}{ Figure 3: Example of a Reflective Tool from the Wage.com Project } \\
\hline $\begin{array}{l}\text { Summary of the Conversation - } \\
\text { Generated by Listening to Audio Tapes }\end{array}$ & $\begin{array}{l}\text { Researcher's Reflections and } \\
\text { Thoughts - at the Time and Upon } \\
\text { Listening to Audio Tapes }\end{array}$ \\
\hline $\begin{array}{l}\text { They had created their new grid scores without } \\
\text { reference to the old one. They had already } \\
\text { collaborated. }\end{array}$ & $\begin{array}{l}\text { This is a clean way to consider the } \\
\text { issues. And they could start without } \\
\text { me. }\end{array}$ \\
\hline $\begin{array}{l}\text { There was an assumption when we started that } \\
\text { "network" referred to the community driving the } \\
\text { business but this was challenged. "It is customer to } \\
\text { company to customer...is like a three pronged thing" } \\
\text { The traditional model is the company and the } \\
\text { customer but G suggests it is the customer, the } \\
\text { company and the other customers. } \\
\text {..... }\end{array}$ & $\begin{array}{l}\text { The words in the tool may have } \\
\text { inhibited the immediate acceptance of } \\
\text { the fundamentally networked nature } \\
\text { of their service; but once we reflect } \\
\text { upon it, we see it. I need to modify } \\
\text { that tool. }\end{array}$ \\
\hline $\begin{array}{l}\text { G "Because our customers go against each other, I } \\
\text { can't think of them in community terms...betting is } \\
\text { such an individual activity.... But they depend on } \\
\text { other customers: "They are not really a collaborative } \\
\text { community." } \\
\text { B refers to when there are discussion boards, they } \\
\text { do communicate directly to each other at times, } \\
\text { asking for specific odds for example. They started off } \\
\text { by having the individual names on the betting sheet } \\
\text { to make that peer-to-peer relationship but this has } \\
\text { failed. The serious better wants to be anonymous. If } \\
\text { they continually win, they don't wish to tip their hand } \\
\text { to those that continually lose as that will impact their } \\
\text { profitability. }\end{array}$ & $\begin{array}{l}\text { For G, the word "community" was a } \\
\text { block as betters, whilst they depend } \\
\text { on other customers, are not a } \\
\text { community. Customers are } \\
\text { competitive and individualistic. G has } \\
\text { difficulty with the term "community" } \\
\text { because the word has a collegial } \\
\text { meaning. Customers are not in a } \\
\text { collaborative community; they are in it } \\
\text { for themselves. }\end{array}$ \\
\hline $\begin{array}{l}\text { We discussed community roles and scanning: } \\
\text { they operate a network and they work with other } \\
\text { networks such as football betting. Then G\&B offered } \\
\text { that we do operate a network and we understand } \\
\text { their role in our site. They referred to the "eco } \\
\text { system" and reflected that they would reassess their } \\
\text { scoring on the tools we had all prepared for the } \\
\text { workshop. }\end{array}$ & $\begin{array}{l}\text { We see the growing realisation that } \\
\text { they are managing an eco system. I } \\
\text { did not find this realisation, or hear } \\
\text { the term, before this meeting - so I } \\
\text { believe that we built this knowledge } \\
\text { together. }\end{array}$ \\
\hline
\end{tabular}

Often, this process is repeated several times. Listening, reflecting, reflecting upon the reflections and repeating the cycle by listening again, mimics the cycles of learning in the main project and helps the researcher draw knowledge from the research process whilst being aware of his or her role within the group.

Aside from enhanced self-awareness, the Action Researcher will have many characteristics of a consultant: Gummesson (2000), a renowned marketing academic, outlines the skills of a consultant-cum-Action Researcher (Gummesson, 2000). They include diagnostic ability, solution skills, knowledge of management 
techniques, communications skills and personal qualities (e.g. ethics and empathy). However AR differs from management consultancy; the research is conducted for the benefit of those affected by its outputs and an express objective of the research is the development of participants' ability to improve their day to day performance. The Action Researcher does not have a prescribed agenda, with firm dates and deliverables to achieve. Nor is the researcher the empty vessel of pure facilitation or inductive research methods - there merely to ensure that everyone has their say and feels able to contribute. The researcher shares the problem and the outcomes and is expected to be a full participant in the research project. The authors outline the characteristics required for AR in Figure 4.

\begin{tabular}{|l|}
\hline \multicolumn{1}{|c|}{ Figure 4: Characteristics of a Good Action Researcher } \\
Concern for the agenda of others \\
Self awareness - sensitive to one's role within the group \\
Sensitive to needs of co-researchers and their role with their organisation \\
Good consulting skills such as gentle persuasion, flexibility, commitment \\
Organised, meticulous note taking and documentation \\
Committed to the process, patience in waiting for the outcomes to emerge \\
Strong sense of ethics
\end{tabular}

Often, the organisation will wish to generalise AR findings in order to benefit other managers facing similar problems. In these cases, the researcher needs to document the learning, perhaps building upon the pages of reflection. The researcher can be a catalyst for transforming an AR project into a community of inquiry that permeates the organisation and builds a ground swell of change from the bottom up.

\section{Conclusions}

Increasingly, the focus of marketing will be to work with customers as co-creators to build value-in-use. This puts pressure on market research methods which must evolve from its current focus on objective analysis (validity) to interactive collaboration (usefulness). Those who have both the desire and skill to lead collaborative Action Research work will balance a number of roles as expert, consultant and co-researcher, as well as the knowledge needed to carry out traditional market research.

In today's economy, where customers are active participants, innovation does not stop at new product development and line extensions refined through qualitative and quantitative testing. AR techniques enable the market researcher to engage more effectively with customers as the co-creators of innovative solutions, whether relational, process-based or indeed new-to-market product offerings. 


\section{Appendix One: The Ten Traditions of Action Research}

Coghlan and Brannick (2001) identify 10 traditions of AR and key authors and writings associated with each.

1. Traditional action research, as practised by K Lewin (1973), is aimed at solving a problem collaboratively whilst generating new knowledge.

2. Participatory action research focuses on the concerns of power and how the powerless are excluded from decision making (Whyte, Greenwood and Lazes, 1991).

3. Action learning focuses on a learning approach to solving problems at work. It is similar to traditional action research, but lacks the focus on generating usable knowledge or theory (Revens, 1998).

4. Action science emphasises the damaging effect of the cognitive processes of individuals' theory-in-use. It suggests that a skilled interventionist can help organisations generate action based upon valid information, free choice and commitment (Argyris and Schön, 1978).

5. Developmental action inquiry develops a new form of leadership based upon inquiry conducted in everyday life, dealing with data encountered in the moment and engendering others to do likewise (Torbert, 1981).

6. Co-operative inquiry is research with people rather than upon people reflecting this tradition's focus on the self-determining nature of people (Heron and Reason, 1999).

7. Clinical inquiry focuses on trained helpers who act as organisational clinicians looking at what constitutes a healthy system and system dynamics (Schein, 2000; Schein, 1987).

8. Appreciative inquiry focuses on learning and reflecting the language and construction of reality of the co-researchers (Cooperrider and Srivastava, 1987).

9. Reflective practice focuses on how individuals engage in critical reflection on their own actions (Schon, 1983).

10. Evaluative inquiry, which is closely related to action research, focuses on inquiry that generates organisational learning (Preskill and Torres, 1999). 


\section{Appendix 2: The Marketing Capabilities Frameworks and Tools}

An analysis of 40 years of marketing has identified four principal marketing capabilities of business-to-consumer marketing:

- Demand management - generating revenue for goods and services.

- Creating marketing knowledge - generating and disseminating - throughout the firm - insight about consumers, markets, competitors, alliance partners, online communities, etc.

- Building brands - creating and maintaining brands for products, services and the organisation.

- Customer relationship management (CRM) - developing how the firm relates to consumers.

The literature also suggests that the detailed content of each of these capabilities coalesces around three types of marketing between companies and consumers: mass marketing - transactions, one-to-one relationships and networks.

The marketing capabilities framework (Figure 5) is therefore in the form of a matrix defined by two axes: the four capabilities cited above and these three forms of marketing relationships.

Figure 5: Marketing capabilities framework.

\begin{tabular}{|c|c|c|c|}
\hline & \multicolumn{3}{|c|}{$\begin{array}{c}\text { Marketing } \\
\text { Relationships }\end{array}$} \\
\hline & $\begin{array}{l}\text { Transactional } \\
\text { relationship }\end{array}$ & $\begin{array}{l}\text { One-to-one } \\
\text { relationship }\end{array}$ & $\begin{array}{l}\text { Networked } \\
\text { relationship }\end{array}$ \\
\hline $\begin{array}{l}\text { Demand } \\
\text { management }\end{array}$ & $\begin{array}{l}\text { Selling, maximize } \\
\text { transactions }\end{array}$ & $\begin{array}{l}\text { Maximize lifetime } \\
\text { value of consumers }\end{array}$ & $\begin{array}{l}\text { Co-creating value with } \\
\text { a network of } \\
\text { consumers }\end{array}$ \\
\hline $\begin{array}{l}\text { Creating } \\
\text { marketing } \\
\text { knowledge } \\
\end{array}$ & $\begin{array}{l}\text { Market trends, } \\
\text { segmentation and } \\
\text { competitive offers }\end{array}$ & $\begin{array}{l}\text { Individual consumers: } \\
\text { needs, purchasing } \\
\text { styles, profitability }\end{array}$ & $\begin{array}{l}\text { Key network } \\
\text { participants and } \\
\text { shapers }\end{array}$ \\
\hline $\begin{array}{l}\text { Building } \\
\text { brands }\end{array}$ & $\begin{array}{l}\text { Product and service } \\
\text { brands }\end{array}$ & Company brands & Network capabilities \\
\hline $\begin{array}{l}\text { Customer } \\
\text { relationship } \\
\text { management } \\
\text { (CRM) }\end{array}$ & Contractual & $\begin{array}{l}\text { Customized and or } \\
\text { negotiated }\end{array}$ & Self-managed \\
\hline
\end{tabular}

This framework was used by Wage.com managers to assess their current and future marketing capabilities in the context of their desired relationship marketing strategy. To make it operational, a Marketing Capability Scoring Tool was generated for each of the 
four marketing capabilities: Figure 6 illustrates a "creating marketing knowledge" capability. There are similar tools for each of the other three marketing capabilities.

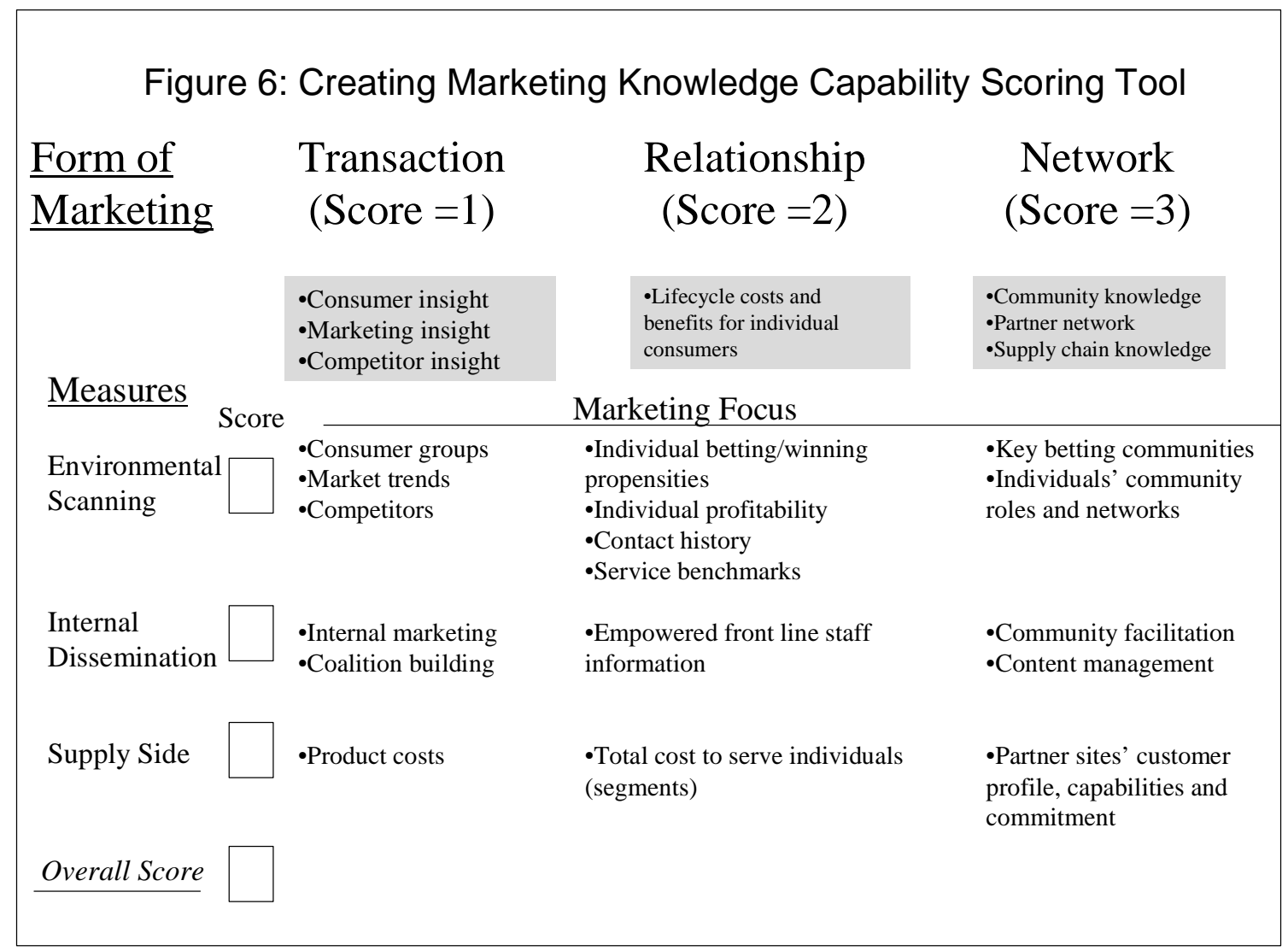

The tools invite managers to score their firm on each of the key measures from 1 to 3 (fractions permitted) and build a weighted average for the capability overall. There is no academic significance to the scores themselves nor any apriori theory suggesting that the three capabilities are equidistant. However the authors have built the tools based upon a rigorous analysis of the marketing literature. Rather than the score per se, it is the cycles of discussion and investigation arriving at an agreed position that is important. The scoring exercise initiated the first workshop in work-cycle 1.

Once managers had agreed upon their current capabilities, they looked at the bundle of their capabilities and supporting assets (brands, customer base, customer insight, partner web sites) in order to determine which, if any, were sources of competitive advantage to their larger rival. To effect this analysis, the authors introduced an assessment tool from the relevant theory about how capabilities create competitive advantage: the Resource Based View. A definitive article by J Barney (1991) suggests that a bundle of capabilities and assets create advantage where they are VRIN: (1) create something of value to customers, (2) are rare such that competitors can't obtain it (3) imperfectly imitable and (4) non substitutable. Over time, Wage.com considered that its insight into, and ability to manage, the complex interaction of key market-makers, winners-losers, backers-layers and partner web sites met all of the above criteria.

Once managers had agreed upon the firm's key marketing capability, they used the above scoring tools (illustrated in Figure 6) again, but this time in the context of future capabilities. Thus the team had created a detailed assessment and description of 
Wage.com's current and desired future capabilities; the gap between them represented the managerial development task. The agreed actions represented the means for bridging the gap and measure of the validity of the AR process. 


\section{References}

1. Ambrosini, V. and Bowman, C. (2001), 'Tacit Knowledge: Some Suggestions for Operationalization', Journal of Management Studies, Vol. 38, No. 6, pp. 811829.

2. Argyris, C. (1973), Intervention Theory and Method: a Behavioural Science View, Addison-Wesley, Reading, Mass.

3. Argyris, C., Putnam, R. and McLain Smith, D. (1985), Action Science, JosseyBass Publications, San Francisco.

4. Argyris, C. and Schön, D. (1978), Organizational Learning: A Theory of Action Perspective, Addison-Wesley, Reading, Mass.

5. Baker, S. and Mouncey, P. (2003), 'The Market Researcher's Manifesto', International Journal of Market Research, Vol. 45, No. 4, pp. 415-433.

6. Barney, J. (1991), 'Firm Resources and Sustained Competitive Advantage', Journal of Management, Vol. 17, No. 1, pp. 99-120.

7. Berger, P. and Luckmann, T. (1966), The Social Construction of Reality, Doubleday, New York.

8. Breu, K. and Peppard, J. (2003), 'Useful Knowledge for Information Systems: The Contribution of the Participatory Paradigm', Journal of Information Technology, Vol. 18, No. 3, pp. 177-194.

9. Checkland, P. (2000), 'Soft Systems Methodology; a Thirty Year Retrospective', Systems Research and Behavioral Science, Vol. 17, pp. s11-s58.

10. Clark, P. (1972), Action Research and Organizational Change, Harper \& Row, London.

11. Coghlan, D. and Brannick, T. (2001), Doing Action Research in Your Own Organization, Sage, London.

12. Cooperrider, D. and Srivastava, S. (1987), 'Appreciate Inquiry in Organizational Life', in Woodman, R. and Pasmore, W.Research in Organizational Change and Development, JAI, Greenwich, pp. 129-169.

13. DeFelice, A. (2006), 'A New Marketing Medium', Customer Relationship Management, Vol. 10, No. 1, pp. 32-35.

14. Gummesson, E. (2000), Qualitative Methods in Management Research, Sage, Thousand Oaks, California.

15. Heron, J. and Reason, P. (1999), 'The Practice of Co-Operative Inquiry: 
Research "With" People Rather Than "On" People', in Bradbury, H. and Reason, P. Handbook of Action Research, Sage, London, pp. 179-188.

16. Ind, N. and Riondino, M. (2001), 'Branding on the Web: A Real Revolution?', Journal of Brand Management, Vol. 9, No. 1, pp. 8-20.

17. Kotler, P. (1972), 'A Generic Concept of Marketing', Journal of Marketing, Vol. 36 , No. 2, pp. 46-54.

18. Kozinets, R.V. (1999), 'E-Tribalized Marketing? The Strategic Implications of Virtual Communities of Consumption', European Management Journal, Vol. 17, No. 3, pp. 252-264.

19. Lewin, K. (1973), 'Action Research and Minority Problems', in Lewin, G. Resolving Social Conflicts: Selected Papers on Group Dynamics, Souvenir Press, London, pp. 201-216.

20. Lilien, G., Morrison, P., Searls, K., Sonnack, M. and von Hippel, E. (2002), 'Performance Assessment of the Lead User Idea-Generation Process for New Product Development', Management Science, Vol. 48, No. 8, pp. 1042-1059.

21. Marshall, A. (1991), 'On Markets', in Thompson, G., Frances, J., Levacic, R. and Mitchell, J. Markets, Hierarchies and Networks, Sage, London, pp. 24-34.

22. Palmer, R. (2005), 'Knowledgeable Uncertainty: Paradox or Paradigm?', International Journal of Market Research, Vol. 47, No. 6, pp. 577-595.

23. Polanyi, M. (1976), 'Tacit Knowing', in Marx, M. and Goodson, F. (Editors), Theories in Contemporary Psychology, Macmillan, New York,

24. Preskill, H. and Torres, R. (1999), Evaluative Inquiry for Learning in Organizations, Sage, Thousand Oaks.

25. Reason, P. and Bradbury, H. (editors) (2001), Handbook of Action Research, Sage, London.

26. Reason, P. (2001), 'Learning and Change Through Action Research', in Henry, J. Creative Management, Sage, London, pp. 182-194.

27. Reason, P. and Bradbury, H. (2000), 'Introduction: Inquiry and Participation in Search of a World Worthy of Human Aspiration', in Reason, P. and Bradbury, $\mathrm{H}$. Handbook of Action Research, Sage, London, pp. 1-14.

28. Revens, R. (1998), ABC of Action Learning, Lemos and Crane, London.

29. Roberts, D., Baker, S. and Walker, D. (2005), 'Can We Learn Together?', International Journal of Market Research, Vol. 47, No. 4, pp. 407-427.

30. Rose, R. and Wood, S. (2005), 'Paradox and the Consumption of Authenticity Through Reality Television', Journal of Consumer Research, Vol. 32, No. 2, pp. 284-296. 
31. Ryals, L. and Wilson, H. (2005), 'Experimental Methods in Market Research', International Journal of Market Research, Vol. 47, No. 4, pp. 347-366.

32. Schein, E. (1987), The Clinical Perspective in Fieldwork, Sage, Newbury Park.

33. Schein, E. (2000), 'Clinical Inquiry/Research', in Bradbury, H. and Reason, P. Sage, London, pp. 228-237.

34. Schon, D. (1983), The Reflective Practitioner, Jossey-Bass, San Francisco.

35. Skolimowski, H. (1994), The Participatory Mind, Arkana (Penguin Books), London.

36. Torbert, W. (1981), 'Why Educational Research Has Been So Uneducational: The Case for a New Model of Social Science Based on Collaborative Inquiry', in Reason, P. and Rowan, R. Human Inquiry: A Sourcebook of New Paradigm Research, Wiley, Chichester, pp. 141-152.

37. Vargo, S. and Lusch, R. (2004), 'Evolving to a New Dominant Logic for Marketing', Journal of Marketing, Vol. 68, No. 1, pp. 1-17.

38. Whyte, W., Greenwood, D. and Lazes, P. (1991), 'Participatory Action Research: Through Practice to Science in Social Research', in Whyte, W. Participatory Action Research, Sage, Newbury Park, pp. 19-55.

39. Womack, J. and Jones, D. (2005), 'Lean Consumption', Harvard Business Review, Vol. 83, No. 3, pp. 59-68.

40. Wood, G. (2002), Flutter's Departure Leaves Bitter Taste, available at: http://sport/guardian.co.uk/horseracing/story/0,,634157,00.html (accessed 2002).

41. Zollo, W. and Winter, S. (2002), 'Deliberate Learning and the Evolution of Dynamic Capabilities', Organization Science, Vol. 13, No. 3, pp. 339-351.

\footnotetext{
'To "back", for example, Manchester United to win the European Football Champions League Cup, one would bet that they will win. To "lay" that bet one would bet that they do not. Traditional book makers laid bets whilst the ordinary betters backed. Online exchanges allowed private betters to lay for the first time.
} 